\title{
オゾン酸化法と電解法の併用による エチレングリコールの分解
}

\author{
（1986 年 7 月 12 日 受 理）
}

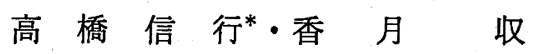

\begin{abstract}
オン゙ン酸化法と電解法の併用（オゾン一電解法）に関する基礎的知見を得るために，エチレングリ 一ルを試料物質として, オゾン一電解法による分解を行なった。

分解反応はエチンングリコールに関して 0.8 次式で表わされ，反応速度定数はオゾン送入濃度が高く なるにつれて增加した。分解生成物としては 4 種の物質が検出された。オゾン酸化法および電解法では不 可能であった全有機炭素 (TOC) の減少も同時に認められ, これは反応過程中で生成される活性ラシシカ ル種によって引き起こされるるのと推定された。また，エチレングリコールの分解経路および脱二酸化 炭素の過程を推察し：シュウ酸を経て脱二酸化炭素を起こす経路とともにギ酸を経由する経路が重要で あり，この経路は主として活性ラジカル種によって引き起こされたものと推定された。さらに，TOC の減少から見た反応条件についても検討を行なった。
\end{abstract}

\section{1 緒言}

オン゙ンの特徵は非常に強い酸化力をもっていることであり, こ れを利用して単に殺菌だけでなく，脱臬，脱色，除鉄・除マンガ ンといった水質改善や，界面活性剤，フェノール，シアン化合物 などの分解に幅広く利用されている。しかしながら，有機化合物 に対するオゾンの酸化作用は選択的であり，有機化合物中の二重 結合、三重結合、ベンゼン環などに作用してこれらを飽和または 開環させるが，一般にはこれら有機化合物を二酸化炭素や水にま で完全に無機化させることは困難である。そのため，これまでに もオゾンの酸化力を増大させるための試みとして, 紫外線照射 ${ }^{1}$, 放射線 ${ }^{2}$ ，超音波 ${ }^{8}$ などとの併用，高 $\mathrm{pH}$ 領域でのオゾン処理 ${ }^{4}$ ， 過酸化水素添加によるオン゙ン処理5などが行なわれてきた。

一方, Kolbe 反応に見られるよらに有機化合物の電解による酸 化はよく知られている方法である。そこで，オゾン酸化と電解酸 化を効果的に併用することによる酸化力の増大が可能であれば, オゾン酸化では無機化せずに処理液中に残留する低分子有機化合 物に対して，それらをさらに分解し無機化できるものと考えられ る。しかしながら，オン゙ン酸化法と不溶性電極を使用した電解法 との併用はこれまでほとんど行なわれておららず，水質指標である 化学的酸素要求量 (以下 $\operatorname{COD}_{\mathrm{Mn}}$ と略記する) の低減に効果が

公害凟源研究所, 305 茨城県筑波郡谷田部町小野川

1) H.W. Prengle, C. G. Hewes, C.E. Mauk, Paper presented at 2 nd Int. Ozone Symp., Int. Ozone Inst., Montreal, Canada (1975).

2）宮田定次郎，新井陸正，野正光，水処理技術，21，129 (1980).

3) E. Dahi, Water Research, 10, 1177(1976).

4) 鈴木 滋, 中山繁樹, PPM, (11), 36(1977).

5) 中山繁樹, 難波敬典, PPM, (5), 30(1979).
あるとの報告がある程度であり ${ }^{6)}$ ，詳細はほとんど知られていな い。

そこで本報告では，オゾン酸化法と不溶性電極を使用した電解 法との併用（以下オゾンー電解法と略記する）に関する基礎的知 見を得るために，試料物質としては，オゾン酸化法および電解法 のどちらか一方でしか分解できない物質（たとえばシュウ酸）を 酸化過程の中に含んでいること，低分子量で構造が簡単なこと， その酸化過程がよく知られて拉りク，しかもそれらの酸化生成物 が容易に純物質として得られることなどからェチレングリコール を選び，その分解生成物，分解機構，分解条件などの検討を行な った。

\section{2 実験}

\section{1 試薬および調製}

エチレングリコールおよび反応生成物のうち，グリュールフ ルデヒド (二量体) は Aldrich 社製試薬, グリオキサールは和光 純薬製化学用, グリオキシル酸は同社製一級試薬, そのほかの物 質は同社製特級試薬をそのまま用いた。

実験に供したエチレングリコール淮は $1.6 \times 10^{-3}, 4.0 \times$ $10^{-8}, 8.0 \times 10^{-3} \mathrm{~mol} \cdot \mathrm{dm}^{-3}$ になるように調製して使用した。ま た，オゾンー電解法ならびに電解法においては, 試料溶液に電気 伝導性を与えるために $10 \mathrm{dm}^{8}$ あたり $\mathrm{NaCl}$ を 10.0,25.0.50.0 $\mathrm{g}$ 加えた。

\section{2 実験装置}

図 1 にこの実験で使用した装盤の概略を示した。接触塔・電解

6）田草川 篤, 松村哲夫, 福场敏夫, 下水道協会誌, 13,51 (1976).

7）化学大辞罡編集委員会編。“化学大辞典”，共立出版 (1960) p. 908. 
Table 1 Conditions of feeding of ozone

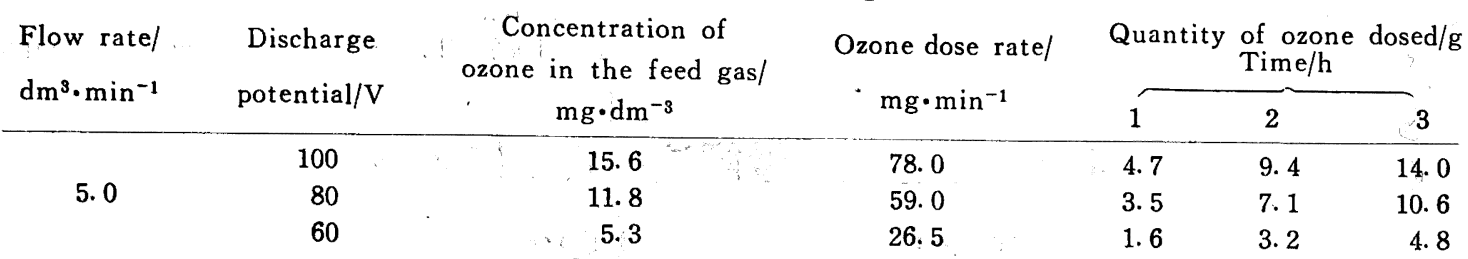

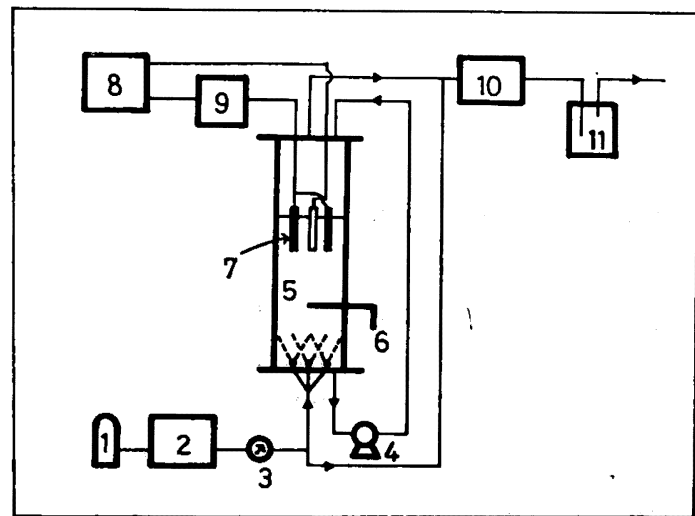

Fig. 1 Schematic diagram of ozone-electrolytic method 1 : Oxygen gas holder, 2 : Ozone generator, $3:$ Flow meter, $4:$ Pump, $5:$ Contact tower $\cdot$ cell, $6:$ Sampling stopcock, 7 : Electrodes ( $\square$-anode, $\square$-cathode), 8: Galvanostat, 9 : Coulomb meter, 10 : Ozone meter, 11 : Exhaust ozone gas absorption tower

槽は内径 $17 \mathrm{~cm}$ ，高さ $65 \mathrm{~cm}$ の透明アクリル樹脂製円筒である。 オソンを含むガスの発生には酸素ガスを使用し，ガス送気量を $5.0 \mathrm{dm}^{3} \cdot \mathrm{min}^{-1}$ とし, オゾン発生機 (日本オゾン製 $\mathrm{NG}-\mathrm{O}_{3}-2$ 型) の放電電压を $60 ， 80 ， 100 \mathrm{~V}$ としてオン゙ン濃度を調整した。表 1 にこれらの条件のもとでの送入オン゙ン淟度，送入速度，送入量を 示した。放電電压を高くするにつれて送入オゾン濃度は高くな り，それにとるない送入速度找よび送入量る多くなり，3時間で の送入量は 4.7 14.0 g であった。このオゾン化ガスを塔底部に 設けた 4 個のガラスボールフィルター（気孔径 $45 \sim 50 \mu \mathrm{m}$ ) を通 して送気し，試料溶夜と気液接触させることによりオゾン酸化を 行ない，気液接触後のオソンン化ガスはヨウ化カリウム溶液を入れ た吸收塔を通したのち，大気中に排気した。送入オジン濃度はオ ソンメーター（萑原実業製 EG-101 X 型）により測定した。電解 反応は定電流装置（日本スタビライザー製 NC-12010 M 型）か ら一定電流を流し，通電量をクーロメーター（北斗電工製 $\mathrm{HF}$ 102 型) で剆定しながら，陽極（TDK 製フェライト電極，100× $100 \times 6 \mathrm{~mm} ， 2$ 枚使用，除極飞は同材質のものを 1 枚使用）飞対 する電流密度を $1.05 ， 2.10 ， 4.25 \mathrm{~A} \cdot \mathrm{dm}^{-2}$ と変化させることに より行なった。なお，接触塔壁面から電極までの距離と電極間距 離をできるだ等間隔となるよらにするため，電極間距離を 3 $\mathrm{cm}$ とした。表 2 に各電流密度のもとでの印加電圧および溶液温 度の変化の一例として, $\mathrm{NaCl} を 0.5 \%$ 添加した場合を示した。 電流密度を上げるにしたかっって印加電圧を高くしなければなら ず、このため溶液温度もとれにともなって上昇したが，電流密度 $1.05 \mathrm{~A} \cdot \mathrm{dm}^{-2}$ の場合には溶夜温度はほとんど变化しなかった。才 ソンー電解反応は同上のオソン酸化法および電解法の操作を同時
Table 2 Changes of potential and temperature of solution

\begin{tabular}{ccrrrr}
$\begin{array}{c}\text { Current } \\
\text { density/ } \\
\mathrm{A} \cdot \mathrm{dm}^{-2}\end{array}$ & & Start & \multicolumn{3}{c}{ Time/h } \\
\hline \multirow{2}{*}{4.25} & $\mathrm{P} / \mathrm{V}$ & 23.0 & 20.5 & 20.0 & 19.5 \\
& $\mathrm{~T} /{ }^{\circ} \mathrm{C}$ & 20.5 & 26.5 & 32.5 & 33.5 \\
2.10 & $\mathrm{P}$ & 14.0 & 13.0 & 13.0 & 12.5 \\
& $\mathrm{~T}$ & 20.0 & 23.0 & 26.0 & 28.5 \\
1.05 & $\mathrm{P}$ & 8.5 & 8.5 & 8.5 & 8.0 \\
& $\mathrm{~T}$ & 19.5 & 20.0 & 20.0 & 20.5
\end{tabular}

P : Potential.

$T$ : Temperature of solution.

Quantity of $\mathrm{NaCl}: 50.0 \mathrm{~g}$.

に行ならことにより実施した。いずれの方法に括りても，1回あ たりの試料溶液は $10 \mathrm{dm}^{8}$ であり, $\mathrm{pH}$ 未調整, 初期温度 $20 \pm 2^{\circ} \mathrm{C}$ のもので 3 時間反応を行なった。

\section{3 分析方法}

エチレングリコールならびに反応生成物の検出には高速液体ク ロマトグラフ（HPLC）（日立製 $635 \mathrm{~A}$ 型）を使用し，検出器と して日立製波長可変 UV モニター（検出波長 $210 \mathrm{~nm}$ ）および昭 和電工製示差屈折計 SE-31 型，カラムとして昭和電工製 Shodex Ionpack C-811 (カラム温度 $40^{\circ} \mathrm{C}$ )，溶離液として $0.1 \%$ リン酸 水溶液（流速 $1 \mathrm{mdm}^{3} \cdot \mathrm{min}^{-1}$ ) により分析を行なった。すなわら, 一定時間ごとに得られた試料溶液について，オン゙ン一電解法なら びにオゾン酸化法においては溶存オゾンによる反応の進行を防ぐ ため採取後窒素ガスを吹き込み（電解法では採取後そのまま）， HPLC に $20 \mu \mathrm{dm}^{3}$ 注入した。反応生成物の同定は標準品のピー クの保持時間との一致から決定し，前もって標準品により作成し て扰いた検量線により定量を行なった。同時に，全有機炭素分析 計（東芝ベックマン製 102 型）により全有機炭素（以下 TOC と 略記する）を測定した。

\section{3 結 果亡考察}

\section{1 反応速度式の検討}

エチレングリコールのオゾンー電解法による分解にさいしての 反応速度式を求めるため，エチレングリコール濃度を変化させ， 初期濃度のピーク面積（保持時問 17.4 分）からの減少に上り所 定時間ごとの分解量を求めた ${ }^{8)}$ 。 $n$ 次反応に批ける反応速度式に 打いて $n=0.8$ と仮定し，各条件下に打㤝 $C_{0}{ }^{0.2}-C^{0.2}$ (ここで, $C_{0}$ および $C$ は時間 $t=0, t$ におけけるエチレングリコール濃度）

8）表 2 における温度变化がほとんど認められなかった電流密 度 $1.05 \mathrm{~A} \cdot \mathrm{dm}^{-2}, \mathrm{NaCl}$ 添加量 $50.0 \mathrm{~g}$ の場合飞ついて検討 を行なった．電流密度 $1.05 \mathrm{~A} \cdot \mathrm{dm}^{-2}$ の場合でも $\mathrm{NaCl}$ 添 加量が $10.0 \mathrm{~g}$ では $6.0^{\circ} \mathrm{C}, 25.0 \mathrm{~g}$ では $3.0^{\circ} \mathrm{C}$ 程度の温度 上年が認められた。 

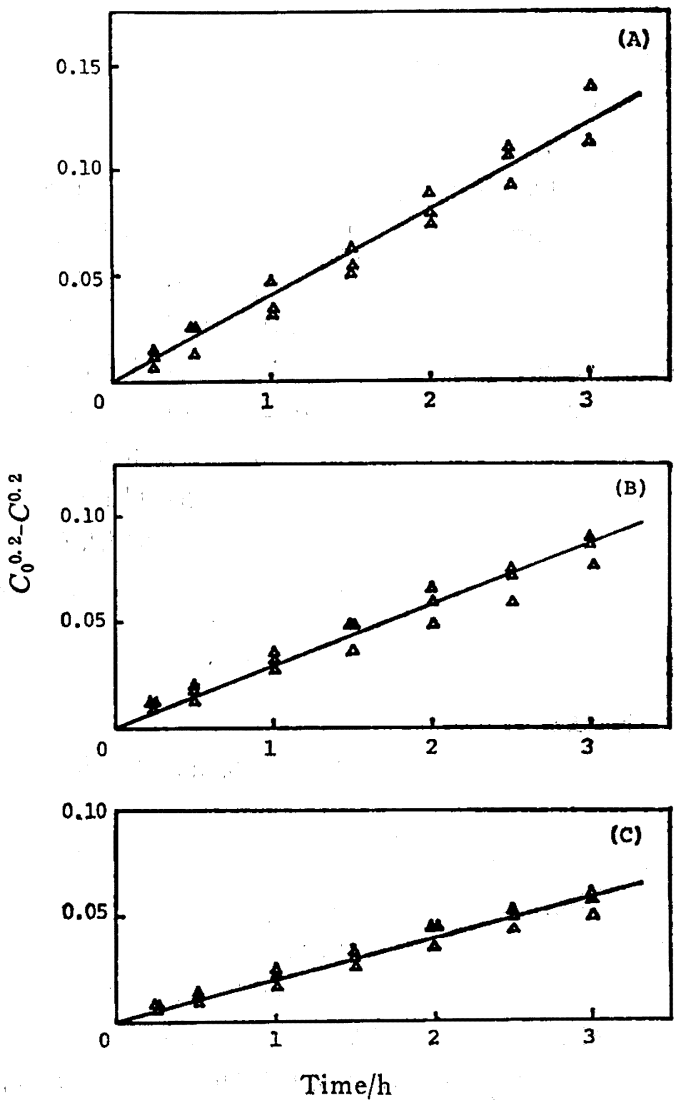

Fig. 2 Relationship between $\left[C_{0}^{0.2-} C^{0.2}\right]$ and time at current density $1.05 \mathrm{~A} \cdot \mathrm{dm}^{-2}$ and quantity of $\mathrm{NaCl}$ $50.0 \mathrm{~g}$

Discharge potential $(\mathrm{V})$ :

(A) $; 100$, (B) $; 80$, (C) $; 60$

と $t$ の関係をプロットし,それらの結果を図 2 に示す。図 2 のプ ロットが直線に乗ることから、エチレングリコールのオソンー電 解法による分解反応の次数を 0.8 とした。この結果, 反応速度式 は次式で表わされることがわかった。また，反応速度定数はオン゙

$$
-\frac{\mathrm{d} C}{\mathrm{~d} t}=k C^{0.78 \sim 0.81} \fallingdotseq k C^{0.8}
$$

ン送入濃度が高くなるにつれて増加した。Eisenhauer は反応速 度定数がオゾンの投与速度に比例すると報告しておりの，本実験 の場合にもこれと一致することが示された。

\section{2 反応生成物の検索}

オゾンー電解法においてェチレングリコール濃度, オゾン送入 淟度, 電流密度, $\mathrm{NaCl}$ 添加量を変化させて反応を行ない，その 生成物の検索を行なったところ, 反応条件によりピーク面積は異 なるものの，示差屆折計によるクロマトグラム上に五つのピーク が認められた。これらは保持時間がそれぞれ 11.4，12.3，13.9, 15. 2, 17.4 分であり, グリオキシル酸, グリオキサール, グリב ールフルデヒド，ホルムフルデヒド，エチレングリコールにそれ ぞれ相当した10)。四3にオン゙ンー電解法によるエチレングリコー

9) H. R. Eisenhauer, J. Water Pollut. Control. Fed., 40, 1887(1968).
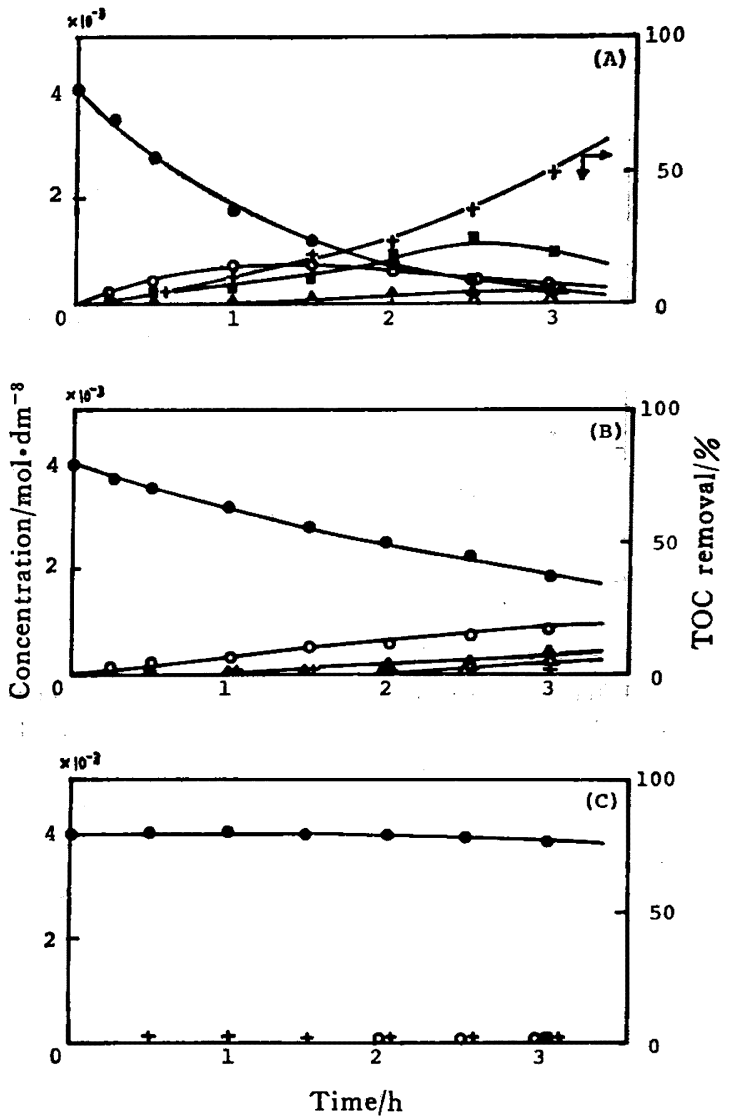

Fig. 3 Decomposition of ethylene glycol and change of its reaction products by ozone-electrolytic method (A), ozone oxidation method (B), and electrolytic method (C), at initial concentration $4.0 \times 10^{-8}$ $\mathrm{mol} \cdot \mathrm{dm}^{-8}$

(A) : Discharge potential $100 \mathrm{~V}$, current density 2.10 $\mathrm{A} \cdot \mathrm{dm}^{-2}$ and quantity of $\mathrm{NaCl} 10.0 \mathrm{~g}$

(B) : Discharge potential $100 \mathrm{~V}$

(C) : Current density $2.10 \mathrm{~A} \cdot \mathrm{dm}^{-2}$ and quantity of $\mathrm{NaCl} 10.0 \mathrm{~g}$

: Ethŷlene glycol, $\bigcirc:$ Glycolaldehyde, $\mathbf{\Delta}$ : Glyoxal, $\triangle$ : Glyoxylic acid, $\square$ : Formaldehyde, $\square$ : Formic acid, + : TOC removal

ルおよびこれら反応生成物の経時変化の一例をオゾン酸化法およ び電解法と比較し示す。溶液温度が高い場合 $\left(30^{\circ} \mathrm{C}\right)$ にオゾン酸 化法で検出されるシュウ酸, 電流密度が高い場合 $\left(4.25 \mathrm{~A} \cdot \mathrm{dm}^{-2}\right)$ に検出されるギ酸は，反応条件のいかんにかかからずオンンー電 解法ではともに検出されなかった。また，オン゙ンー電解法ではオ ゾン酸化法および電解法では認めることができなかった TOC の 減少が認められた。これに対して，オソン酸化法では溶液温度が

10）文献 7)によるとグリコールフルデヒドからグリオキシル 酸への酸化はタリオキサールおよびグリコール酸を軽由す る二通りが示されている．また、グリコール醊の保持時間 は 14.1 分であり、クリコールアルデヒドのそれと接近し ている. そのため 3-メチル-2-ベンソチフゾロンヒドラッ ン試臥によるアルデヒドの定性分析により両者の識別を行 なった，日本分析化学会楅，“分析化学便監”, 改訂 2 股。 丸善 (1971) p. 342 . 


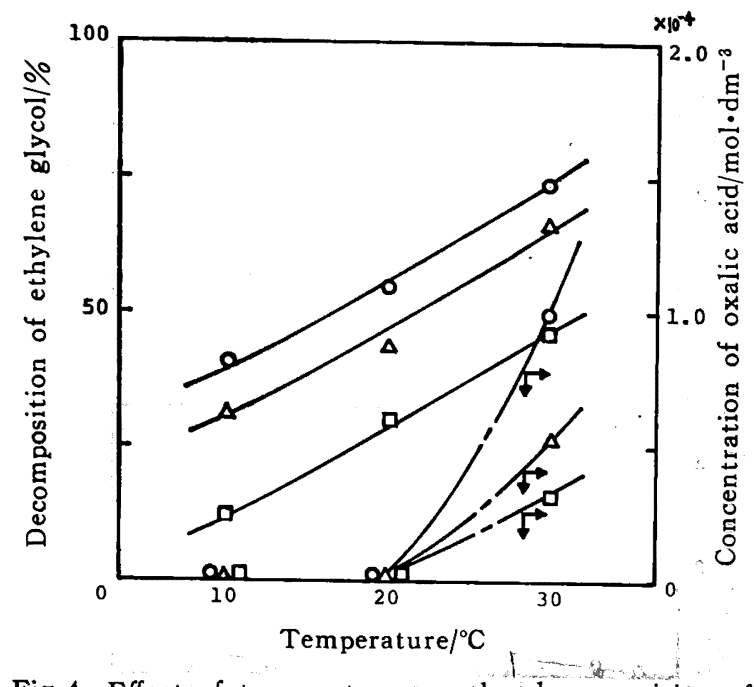

Fig. 4 Effect of temperature on the decomposition of ethylene glycol (-) and production of oxalic acid by ozone oxidation method (- - - - ) at reaction time $3 \mathrm{~h}$ and initial concentration $4.0 \times$ $10^{-3} \mathrm{~mol} \cdot \mathrm{dm}^{-3}$

Discharge potential $(\mathrm{V}): \bigcirc ; 100, \triangle ; 80, \square ; 60$

高くなるほど、また、オゾン送入量が多くなるほど分解が進行 し，それにともないシュウ酸の生成量が增大した。これらの結果 の一例を図 4 に示す。しかしながら，オゾンによる酸化ではシュ ウ酸が酸化の最終段階にあることからそれ以上の分解は起こら ず, TOC の減少はまったく認められなかった。また，電解法では 電流密度が高くなるほど分解が進行したが，アルコールの酸化電 位は一般に高く、アルコールを直接酸化して能率よくアルデヒド に変えることは容易ではないと指摘されているよらに吕，電流密 度が高い $4.25 \mathrm{~A} \cdot \mathrm{dm}^{-2}$ の場合でるさほど分解は進んでおらず,
分解生成物としてはグリコールアルデヒド，ホルムアルデヒドお よびギ酸がわずかに認められる程度であった。これらの結果の一 例を図 5 に示す。また，オゾン酸化法と同様に TOC の減少はま ったく垫められなかった。

オゾンー電解法では反応条件のいかんにかかわらず TOC の減 少を認めることがでさたので，さらにその分解力を検討するた め, 各方法における反応生成物として検出された 6 種類の物質に ついて TOC の減少率を测定した。それらの結果の一例を表 3 に 示す。オゾン酸化法ではホルムアルデヒドおなびギ酸に対しての み 12)，また，電解法ではホルムアルデヒドを除いたほかの物質に 対して TOC の減少が認められたが，オン゙ン一電解法ではこれら すべての物質に対してオゾン酸化法および電解法以上の TOC の 減少が認められた。これらのことから，オン゙ン一電解法ではオゾ ン酸化法と電解法の併用による相乗効果により，それぞれの方法 と比較し強力な酸化分解能を有することが特徵としてあげられる ことがわかった。

\section{3 分解能の検討}

前節での検討から，オン゙ン一電解法では併用による相乗効果に より強力な酸化分解能を有することがわかったので，つぎにこの 相乗效果の中身について検討を行なった。すなわち，オン゙ンと電 解作用との相互作用を検討する目的で, オン゙ンを邻がスの代わ りに酸素ガスを吹きこみながらの電解法による TO\& の減少を調 べた。また，本実験では試料溶液に $\mathrm{NaCl}$ を添加しており，電解 による酸化還元反応と競争する形で $\mathrm{NaCl}$ の電解も起こり，しか も隔膜を使用していないために生成する $\mathrm{OH}^{-}$が陽極へ拡散移動 するために $\mathrm{ClO}^{-}, \mathrm{ClO}_{3}^{-}$なども生成し ${ }^{13)}$ ，これらも酸化反応に寄 与するものと予想される。そこで，これら塩素化合物による効果 を検討する目的で, 塩素化合物を生じない塩 $\left(\mathrm{Na}_{2} \mathrm{SO}_{4}\right)$ を使用し てのオゾンー電解㳂 ${ }^{14)}$, 塩素化合物の代表として $\mathrm{NaClO}$ を取り上

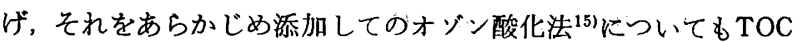
の減少を調べた。

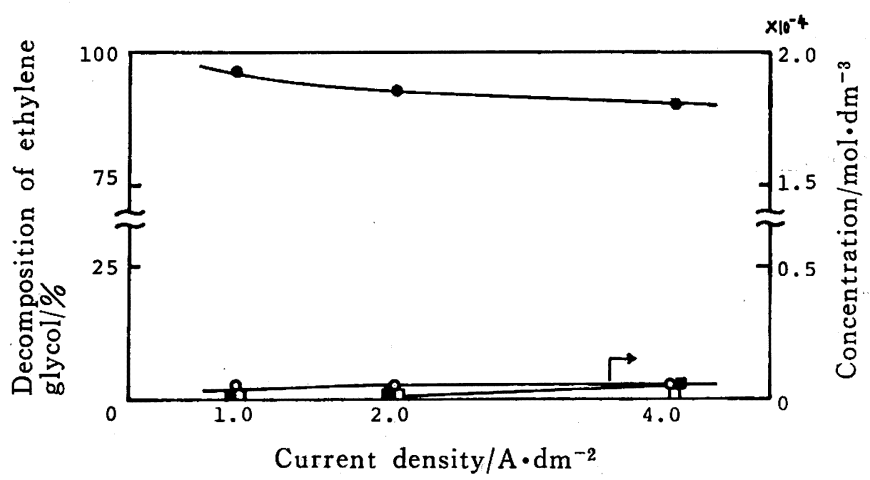

Fig. 5 Effect of current density on the decomposition of ethylene glycol (O) and production of glycolaldehyde (O), formaldehyde $(\square)$ and formic acid $(\square)$ by electrolytic method at reaction time $3 \mathrm{~h}$, initial concentration $4.0 \times 10^{-3} \mathrm{~mol} \cdot \mathrm{dm}^{-3}$ and quantity of $\mathrm{NaCl} 10.0 \mathrm{~g}$

11）鳥居 滋, “有機電解合成”, 講談社 (1981) p. 262.

12) Y. Yàmamoto, E. Niki, H. Shiokawa, Y. Kamiya, J. Org. Chem., 44, 2137(1979).

13）電気化学協会編，“電気化学便覧”，丸善（1964）p.748.
14) $\mathrm{Na}_{2} \mathrm{SO}_{4}$ は $\mathrm{NaCl}$ のイオン強度と等しくなるように添加し

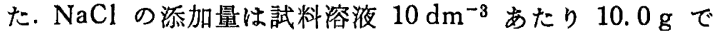

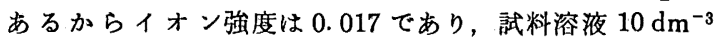
あたりの $\mathrm{Na}_{2} \mathrm{SO}_{4} \cdot 10 \mathrm{H}_{2} \mathrm{O}$ の添加量は $18,4 \mathrm{~g}$ となる. 
Table 3 TOC removal by ozone-electrolytic method, ozone oxidation method and electrolytic method

\begin{tabular}{lcrrrrr}
\multicolumn{1}{c}{ Method } & $\begin{array}{c}\text { Glycol- } \\
\text { aldehyde }\end{array}$ & Glyoxal & $\begin{array}{c}\text { Glyoxylic } \\
\text { acid }\end{array}$ & $\begin{array}{c}\text { Oxalic } \\
\text { acid }\end{array}$ & $\begin{array}{c}\text { Form- } \\
\text { aldehyde }\end{array}$ & $\begin{array}{c}\text { Formic } \\
\text { acid }\end{array}$ \\
\hline Ozone-electrolytic method & 86 & 87 & 98 & 100 & 74 & 100 \\
Ozone oxidation method & 0 & 0 & 0 & 0 & 59 & 100 \\
Electrolytic method & 9 & 41 & 60 & 95 & 0 & 50
\end{tabular}

Concentration of each material : $4 \times 10^{-3} \mathrm{~mol} \cdot \mathrm{dm}^{-3}$.

Reaction time : $3 \mathrm{~h}$.

Ozone-electrolytic method: Discharge potential $100 \mathrm{~V}$, current density $2.10 \mathrm{~A} \cdot \mathrm{dm}^{-2}$, quantity of $\mathrm{NaCl} 10.0 \mathrm{~g}$.

Ozone oxidation method: Discharge potential $100 \mathrm{~V}$.

Electrolytic method: Current density $2.10 \mathrm{~A} \cdot \mathrm{dm}^{-2}$, quantity of $\mathrm{NaCl} 10.0 \mathrm{~g}$.

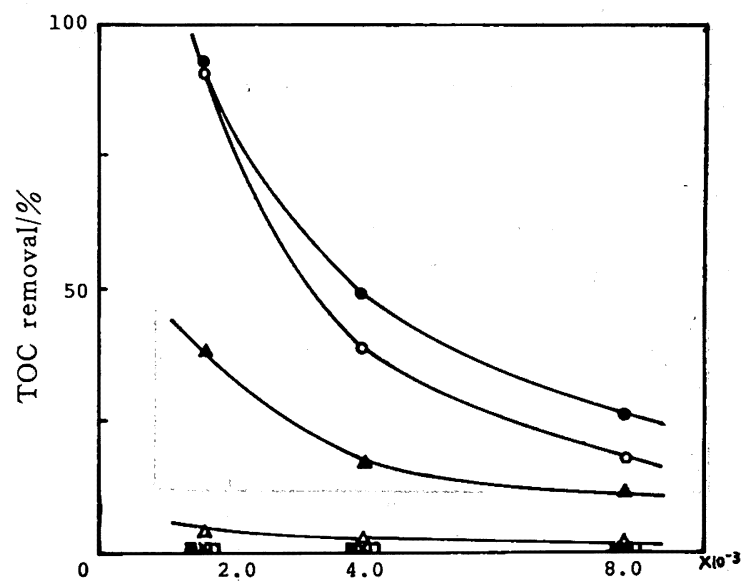

Initial concentration of ethylene $\mathrm{glycol} / \mathrm{mol} \cdot \mathrm{dm}^{-3}$

Fig. 6 Comparision of TOC removal by various methods at reaction time $3 \mathrm{~h}$

: Ozone-electrolytic method using $\mathrm{NaCl}$ (discharge potential $100 \mathrm{~V}$, current density $2.10 \mathrm{~A} \cdot \mathrm{dm}^{-2}$ and quantity of $\mathrm{NaCl} 10.0 \mathrm{~g}$ )

$\mathrm{O}:$ Ozone-electrolytic method using $\mathrm{Na}_{2} \mathrm{SO}_{4}$

$\Delta$ : Ozone oxidation method plus $\mathrm{NaClO}$

$\triangle:$ Ethylene glycol solution plus $\mathrm{NaClO}$

: Electrolytic method plus oxygen gas

$X$ : Ozone oxidation method (discharge potential 100 V)

$\square$ : Electrolytic method (current density $2.10 \mathrm{~A} \cdot \mathrm{dm}^{-2}$ and quantity of $\mathrm{NaCl} 10.0 \mathrm{~g}$ )

図6にこれら各方法によるTOC 除去の効果を, オゾン一電解 法, オゾン酸化法, 電解法のそれぞれと比較し示す。この結果, 塩素化合物の影響を考虑しなくてもよい $\mathrm{Na}_{2} \mathrm{SO}_{4}$ を添加しての オゾンー電解法でも TOC の減少が認められることから，オゾン と電極表面あるい電極近傍での相互作用が, また, $\mathrm{NaClO}$ をあ らかじめ添加してのオン゙ン酸化法でも TOC の減少が認められる ことから，オン゙ンと電解作用によって生成される熄素化合物との

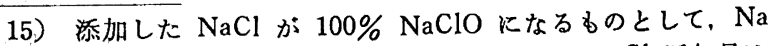
$\mathrm{ClO}$ 溶液（有効塩素 $10 \%$ ）を添加した. $\mathrm{NaCl}$ 添加量は $0.17 \mathrm{~mol}, \mathrm{NaOCl} 10 \mathrm{~g}$ は $0.028 \mathrm{~mol}$, 反応式は $2 \mathrm{Cl}^{-} \rightarrow$ $\mathrm{ClO}^{-}$であることから， NaOCl の添加量は (10) (0.17)/ (2) $(0.028) \fallingdotseq 30.7 \mathrm{~g}$ となる.
相互作用も考えられる。そのため，これら二つの相互作用が同時 に考えられる $\mathrm{NaCl}$ を添加してのオン゙ンー電解法では上記の各方 法よりも TOC の除去は良好であった。また，これら二つの相互 作用がまったく考えられない酸素がスを吹きこみながらの電解法 ではまったく TOC の減少が認められなかったことから、これら 二つの相互作用が併用による相乗効果の主たるものと考えられ る。また，これらの相互作用以外にも，電解作用による溶液温度 の上昇によりオゾン酸化法で生成されるシュウ酸が電解法により 分解されること，扣よび，電解法により生成されるギ酸がオゾン 酸化法により分解されること副などによってすTOC の減少は可 能であるが，これらシュウ酸およびキ酸の量はともにごく微量で あるからこれらの分解により引き起こされる効果はさほど重要 とは思われない。

従来行なわれてきたオン゙ン酸化法とほかの方法との併用におい ては，オゾンを酸化剈として直接利用するものではなく，オソン の分解過程で生じるヒドロキシルラジカル $(\cdot \mathrm{OH})$ を始めとする 活性ラジカルを利用することが示されている(1) こ)。こらのこと を考慮すると，オゾン一電解法に打ける上述のオゾンと奄極表面 あるいは電極近傍での相互作用により，Weiss ${ }^{17}$, GorbenkoGermanov $5^{18)}$, Hochanansal ${ }^{19}$, Adams $5^{201}$ が指摘している以 下に示すよらな反応が，また，オゾンと電解反応によって生成さ

$$
\begin{aligned}
& \mathrm{O}_{3}+\mathrm{OH}^{-} \longrightarrow \mathrm{O}_{2}^{-}+\mathrm{HO}_{2}{ }^{17)} \\
& \mathrm{O}_{3}+\mathrm{OH}^{-} \longrightarrow \mathrm{O}_{3}^{-}+\cdot \mathrm{OH}^{(8)} \\
& . \mathrm{OH}+\mathrm{OH}^{-} \longrightarrow \mathrm{O}^{-}+\mathrm{H}_{2} \mathrm{O}^{(9)} \\
& \mathrm{O}^{-}+\mathrm{O}_{2} \longrightarrow \mathrm{O}_{3}^{-20)}
\end{aligned}
$$

れる塩素化合物との相互作用により以下に示すよらな反応が起こ ることによって,・OH, $\mathrm{HO}_{2}, \mathrm{O}_{3}{ }^{-}, \mathrm{O}_{2}^{-}, \mathrm{O}^{-}$などの活性ラジカル

$$
\mathrm{O}_{3}+\mathrm{ClO}^{-}+\mathrm{H}_{2} \mathrm{O} \longrightarrow \mathrm{ClO}_{3}^{-}+2 \cdot \mathrm{OH}^{21}
$$

種が生成され，それらにより TOC の減少が引き起こされたもの と推定される。

16）電気化学協会編，“電気化学便覧”，丸善（1964）p.519.

17) J. Weiss, Trans. Far. Soc., 61, 702(1935).

18) D.S. Gorbenko-Germanov, I. V. Kozlova, Dokl. Akad. Nauk., 210, 851(1973).

19) C. J. Hochanansal, Radiat. Res., 17, 141(1962).

20) E. G. Adams, W. J. Boag, B.D. Michael, Nature, (London)., 205, 898(1965). 

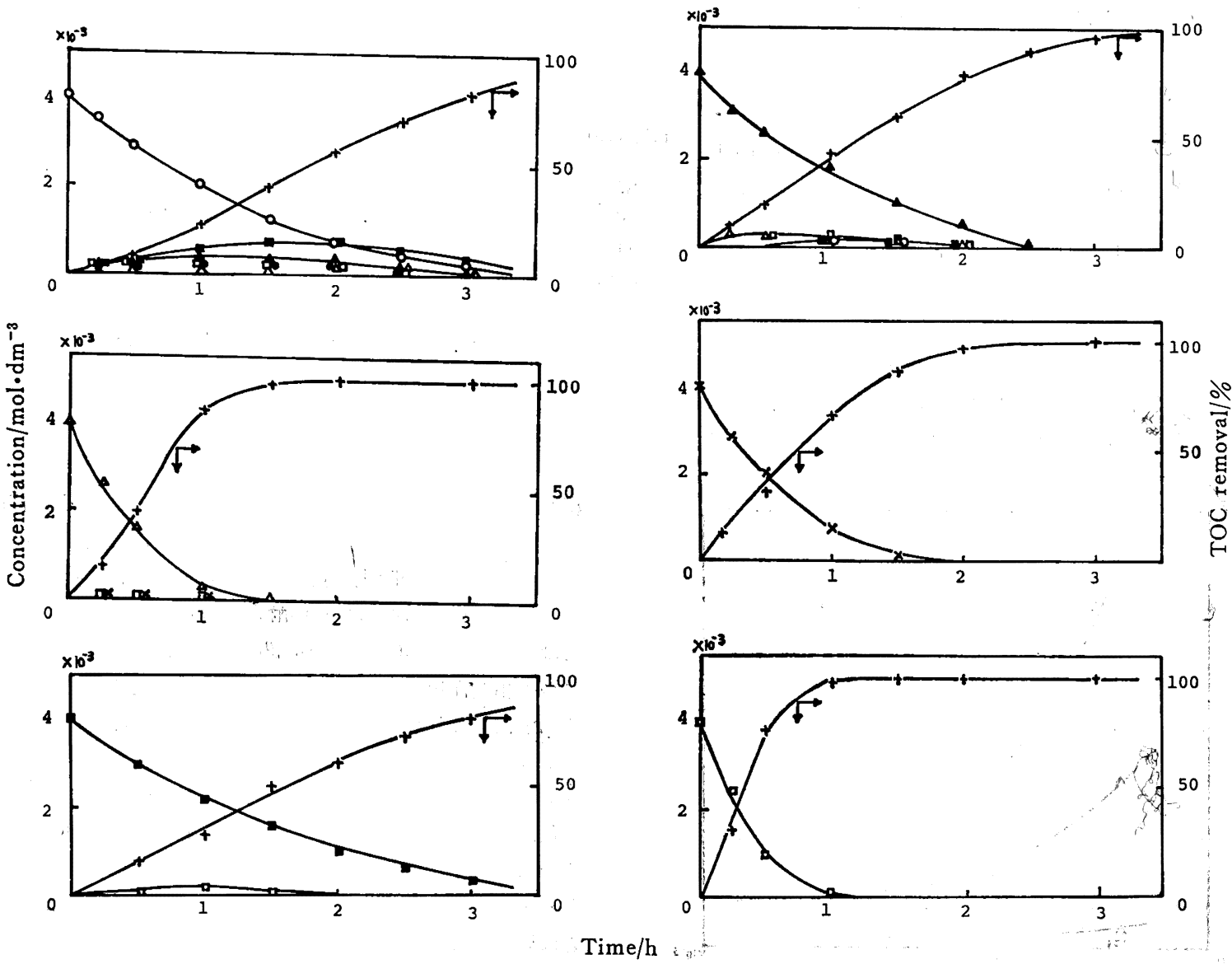

Fig. 7 Decomposition of various materials and changes of their reaction products by ozone-electrolytic method at initial concentration $4.0 \times 10^{-3} \mathrm{~mol} \cdot \mathrm{dm}^{-3}$, discharge potential $100 \mathrm{~V}$, current density $2.10 \mathrm{~A} \cdot \mathrm{dm} \mathrm{m}^{-2}$ and quantity of $\mathrm{NaCl} 10.0 \mathrm{~g}$

: Ethylene glycol, $\mathrm{O}:$ Glycolaldehyde, : Formic acid, + : TOC removal

\section{4 分解機汬の検討}

エチレンクリリコールのオゾンー電解法による分解過程および TOC の減少過程を考察するため，分解過程中に現われた 4 種の 中間生成物およびシュウ酸, キ酸についてもオン゙ンー電解法を行 ない, 反応生成物の経時変化扣よび TOC の減少を調べた。その 結果を図 7 に示す。オゾン一電解法においてはオゾンによる酸化 作用, 電解による陽極での酸化作用, 陰極での還元作用がはたら くが，酸化作用の方がより強力なために溶液全体としては酸化さ れるものと考えられる。本実験では隔膜を使用していないために 反応溶液の混合が起こり, 出発物質あるいは生成物質の分解速度 によっては溶液中に還元物質が検出されることも予想される。グ リコールアルデヒドおよびグリオキサールではエチレングリコー ルおよびクリコールアルデヒドがそれぞれ微量ではあるが検出さ れており，これらは陰極での還元作用により生成されたものと思

21） TOC の減少が引き起こされることから推定した. $\mathrm{NaOCl}$ を添加してのオソン酸化に拈いて, 反応中溶液が黄色に着 色しなかったことから $\mathrm{ClO}_{2}^{-}$は生成されていないるのと 思われる.この反応のほかにも, $\mathrm{O}_{3}+\mathrm{OCl}^{-} \rightarrow 2 \mathrm{O}_{2}+\mathrm{Cl}^{-}$, $2 \mathrm{O}_{3}+\mathrm{OCl}^{-} \rightarrow 2 \mathrm{O}_{2}+\mathrm{ClO}_{3}^{-}, \mathrm{O}_{3}+\mathrm{ClO}_{3}^{-} \rightarrow \mathrm{O}_{2}+\mathrm{ClO}_{4}^{-}$な の反応も推定できる.W. R. Haag, J. Hoigé, Water Res., 17, 1397(1983).

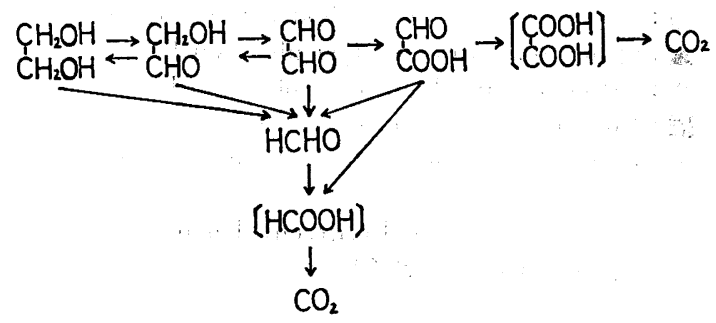

Scheme 1

われるが，グリオキシル酸，シュウ酸，ホルムアルデヒドおよび キ酸では相当する還元物質は検出されなかった。グリコールアル デヒドおよびグリオキサールではホルムアルデヒドが，グリオキ シル酸ではキ酸が検出されたが，これらは炭素-炭素結合の切断 により生成されたものと思われる。ホルムアルデヒドはエチレン グリコールの分解に怙いてもグリコールアルデヒドと同様に反応 開始值後から検出されており，グリコールアルデヒドからの生成 速度はさ汪ど速くないことから，ェチレングリコールからも直接 生成されるものと思われる。グリオキシル酸の分解過程に拈ける 中間生成物として，シュウ酸拉よびギ酸がごくわずかに検出され ているがホルムアルデヒドはまったく検出されなかった。ホルム 

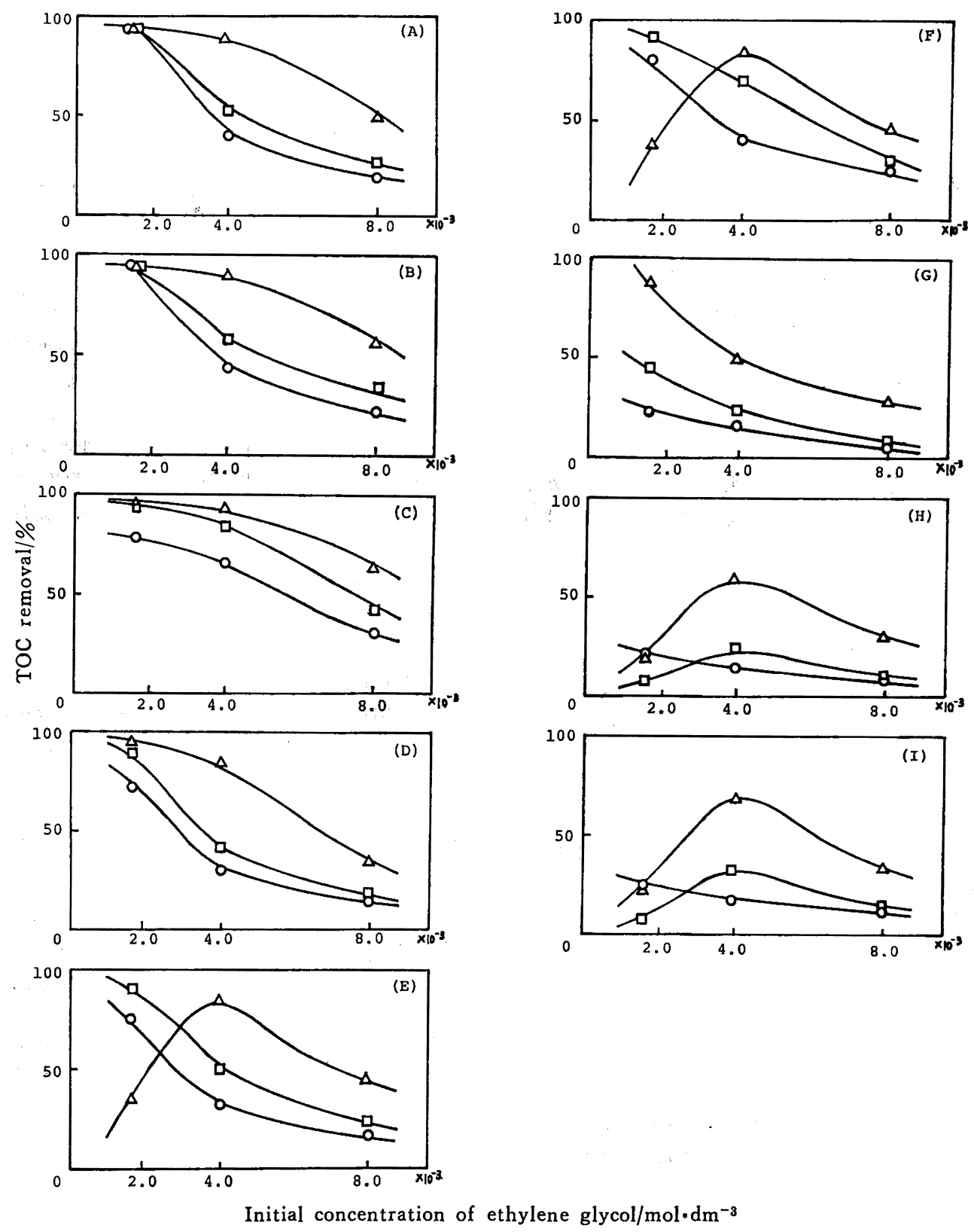

Fig. 8 Effects of reaction conditions on TOC removal

Current density $/ \mathrm{A} \cdot \mathrm{dm}^{-2}: \triangle ; 4.25, \square ; 2.10, \mathrm{O} ; 1.05$

Discharge potential/V : (A), (B), (C); 100, (D), (E), (F) ; 80, (G), (H), ( I ); 60

Quantity of $\mathrm{NaCl} / \mathrm{g}:(\mathrm{C}),(\mathrm{F}),(\mathrm{I}) ; 50.0$, (B), (E), (H) ; 25.0, (A), (D), (G) ; 10.0

アルデヒドはグリオキシル酸の炭素-炭素結合の切断によりキ酸 と等量生成されるが，グリオキシル酸からの生成速度よりるキ酸 への分解速度の方が大きいために㭘出されなかったものと思われ る。また：シュウ酸拈よびギ酸は分解速度が速く，1〜1.5 時間 で完全に分解された。これらの結果をもとに，エチレングリコー ルのオゾンー電解法による分解経路および脱二酸化炭素の過程を 組み立てて図式 1 に示す。

エチレングリコールの分解では反応開始直後からグリコールア ルデヒドが生成され，1時間前後でピークとなり以後しだいに減 少した。グリオキサールはグリコールアルデヒドが減少し始める
ころからしだいに增加したが，比较的分解も速いためにわすがし か検出されなかったものと思われる。ホルムアルデヒドは反应開 始直後から増加し，2〜3 時問では此較的多量に検出されたが，こ れはエチレングリコールのみならずグリコールアルデヒド，グリ オキサール，グリオキシル酸などの分解からる生成されることに よるものと思われる。シュウ酸およびギ酸は反応過程中でまった く愉出されなかったが、これらは一時的には生成されるがすみゃ かに分解され，TOC の減少を引き起こしたものと推定される。 反応過程中に比較的多量のホルムアルデヒドが榆出されることか ら, TOC の減少過程において、シュウ酸 $\rightarrow$ 二酸化炭素の䅅路と 
ともにギ酸 $\rightarrow$ 二酸化炭素の経路もかなり重要であると思われる。 電解法たけですホルムアルデヒドの生成が認められるがごく微量 であることから，主としてこの経路は併用による相乗効果により 生成される活性ラジカル種によって引き起こされたものと推定さ れる。

\section{5 反応条件の検討}

オゾンー電解法では反応条件のいかんにかかわらず TOC の減 少を認めることができたので, オゾン送入浱度, 電流密度, $\mathrm{NaCl}$ 添加量, エチレングリコール濃度などの反応条件が TOC の減少 におよぼす影響について検討し，その結果を図 8 に示す。全般的 にはエチレングリコール濃度が低くなるにしたがって除去率は高 くなり，その場合、オゾン送入濃度および電流密度を高くし $\mathrm{NaCl}$ 添加量を多くするほど良好な除去率が得られたが, オン゙ン送入濃 度が低い場合には， $\mathrm{NaCl}$ 添加量を多くし電流密度を高くすると エチレンクリリコール濃度を低くしても除去率は高くならず，かえ って低下しており，特殊な濃度依存性が認められた。このよう に, TOC の減少はオゾン酸化条件ならびに電解条件のほかにエ チレングリコール濃度によってもいちじるしい影響を受けること がわかった。

これまでの検討から，TOC 除去におよぼす主たる効果は活性 ラジカル種によるものと推定できるので，従来から行なわれてき たオゾン酸化法とほかの酸化法との併用法の原理と同様に, オゾ ンー電解法ではオゾン酸化法により活性種の原料（オゾン）を供 給し，電解法で励起させることにより活性ラジカル種が生成され るものと考えることができる。したがって, 被酸化物濃度を考虑 した上でのオン゙ン酸化法と電解法のバランス，すなわち供給され るオゾン量に見合ら電解条件（あるいは電解条件に見合らオゾン 量の供給）が重要となる。そのため，供給されるオゾン量が少な い状態で電解作用のみを高くしても，活性ラジカル種を生成させ る作用以外に発熱や気泡発生などの副作用を増加させることにな り，このような状態のもとで被酸化物濃度が少ない場合には活性 ラジカル種との反応が妨害されるとともに，活性ラジカル種同志 の再結合による不活性化反応 (たとえば $4 \cdot \mathrm{OH} \longrightarrow 2 \mathrm{H}_{2} \mathrm{O}+\mathrm{O}_{2}$ ) が引き起こされ22)，その結果除去率が低下するものと推定され， 特殊な濃度依存性を示す一因と考えられる。また，エチンングリ
コール濃度が低い状態でオゾン送入濃度を低く $\mathrm{NaCl}$ 添加量を多 く電流密度を高くすると, 反応溶液はしだいに暗褐色を帯び，反 応後の溶液中には沈殿物が認められた。これは電極の溶解による ものと推定され ${ }^{23)}$, この溶解作用が起こることにより，オン゙ンと 電極表面あるいは電極近傍での相互作用による活性ラジカル種の 生成そのものが妨げられることも推定され，このことも特殊な浱 度依存性を示す一因と考えられる。

\section{4 結 言}

エチレングリコールを試料物質としてオゾンー電解法による分 解を行なった。その結果，（1）分解反応はエチレングリコールに 関して 0.8 次式で表わされ, 反応速度定数はオゾン送入濃度が高 くなるにつれて增加すること，（2）分解生成物としてはグリュ ールアルデヒド, グリオキサール，グリオキシル酸和よびホルム アルデヒドの 4 種が検出されるとともに TOC の減少す認められ て拉り，オン゙ン酸化法と電解法の併用により強力な酸化分解能を 有することが特敳としてあげられること，（3）TOC の減少を引 き起こす酸化分解能の主たる効果は活性シジカル種によるものと 推定されること，（4）TOC の減少過程に扣いては，シュウ酸を 経て脱二酸化炭素を起こす経路とともにギ酸を経て脱二酸化炭素 を起こす経路も重要であること，(5) TOC の減少はオン゙ン酸化 条件ならびに電解条件のほかにエチレングリュール浱度によって もいちじるしい影響を受けることがわかった。

オゾン酸化法と電解法の併用についてはこれまでのところほと んど実施例がなく，その詳細はほとんど知られていなかったが， 本実験により若干の知見を得ることができた。しかし，実際に本 法を応用するにさいしてはェチレングリコール拉よびその酸化物 以外の物質への適用性, 電解質の添加効果, 反応にさいしての経 済性などを含めた広範な検討がさらに必要である。

22）加藤民彦，藤嶋 昭，前川悦朗，本多建一，日化，1986， 1.

23）フェライト溶解の举動はつぎのように推定される. $\mathrm{Me}$ $(\mathrm{X})^{2+} \cdot \mathrm{Fe}(1-\mathrm{X})^{2+} \cdot \mathrm{Fe}_{2} \mathrm{O}_{4} \rightarrow \mathrm{MeO}+\mathrm{Fe}_{2} \mathrm{O}_{3}, \quad \mathrm{Fe}_{2} \mathrm{O}_{3}+6 \mathrm{H}^{+}$ $+2 \mathrm{e}^{-} \rightarrow 2 \mathrm{Fe}^{2+}+3 \mathrm{H}_{2} \mathrm{O}, \quad \mathrm{Fe}^{2+} \rightarrow \mathrm{Fe}^{3+}+\mathrm{e}^{-}$横山効生, 金 子保秀, TDK(株)技術資料, 1983, 1 . 


\title{
Decomposition of Ethylene Glycol by the Combined Use of Ozone Oxidation Method and Electrolytic Method
}

\author{
Nobuyuki TAKAHASHI and Osamu KatsuKI \\ National Research Institute for Pollution and Resources; \\ Yatabe-cho, Ibaraki 305 Japan
}

Decomposition of ethylene glycol by the combined use of an ozone oxidation method and an electrolytic one was studied by changing the concentration of ozone in the feed gas, the current density, the quantity of $\mathrm{NaCl}$ and the concentration of ethylene glycol.

The order of the reaction with respect to ethylene glycol was 0.8 and the rate constant increased with an increase of the concentration of ozone in the feed gas. Glycolaldehyde, glyoxal, glyoxylic acid and formaldehyde were detected as decomposition products, and the removal of total organic carbon (TOC), which was not attained by eithers of the two methods, was attained. This effect is considered to be caused by active radicals which are formed during the course of this reaction. The decomposition route is estimated as follows.

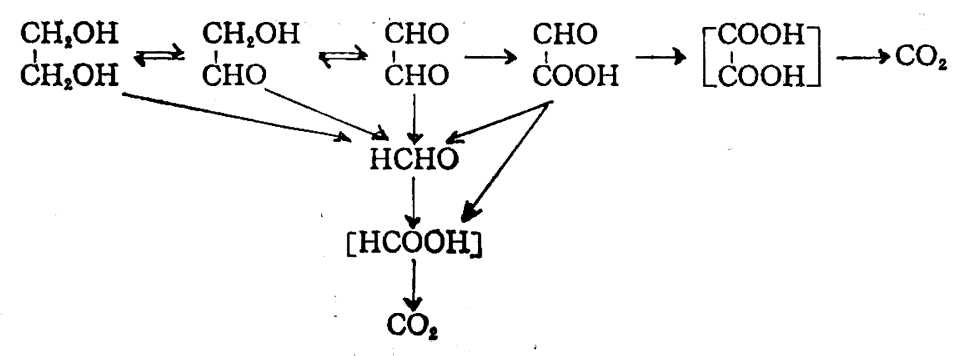

From this scheme and the fact that a considerable amount of formaldehyde produced, is likely that the TOC removal via formic acid is important as well as that via oxalic acid. The TOC removal was remarkably affected by the concentration of ethylene glycol in addition to the conditions of ozone oxidation and electrolysis method. 